\title{
Recovery of Rutin from Labisia pumila Extract Using Solid Phase Extraction
}

\section{Lee Suan Chua, ${ }^{1,2, *}$ Nur Nabihah Ruzlan ${ }^{1,2}$ and Mohamad Roji Sarmidi ${ }^{1}$}

\author{
${ }^{1}$ Metabolites Profiling Laboratory, Institute of Bioproduct Development, Universiti Teknologi Malaysia, \\ 81310 UTM Skudai, Johor Bahru, Johor, Malaysia. \\ ${ }^{2}$ Department of Bioprocess and Polymer Engineering, Faculty of Chemical and Energy Engineering, \\ Universiti Teknologi Malaysia, 81310 UTM Skudai, Johor Bahru, Johor, Malaysia. \\ * Corresponding author: E-mail: chualeesuan@utm.my \\ Tel.: +6019-7214378; fax: +607-5569706
}

Received: 05-17-2017

\begin{abstract}
Reflux extraction was used to prepare crude extract from the leaves of Labisia pumila var. Alata using $60 \%$ methanol. The crude extract was subsequently fractionated by C18 solid phase extraction to recover high yield of rutin using $20-100 \%$ methanol. The volume of eluent to recover rutin was found to decrease with the increase of methanol concentration. The recovery of rutin was increased from 20 to $80 \%$ methanol system, but slightly decreased in the $100 \%$ methanol system. Approximately, $70 \%$ of rutin could be recovered using the $80 \%$ methanol system. This solvent system also appears to have the lowest distance $\left(9.44 \mathrm{MPa}^{1 / 2}\right)$ for rutin as estimated by Hansen solubility. The recovered rutin rich fraction could achieve up to $3.96 \mathrm{mg} / \mathrm{g}$ of fraction which was about 4 -fold increment from the crude extract. The increment was also noticed for its antioxidant capacity expressed as scavenging activity which was 2 times higher than crude extract. A portion of water (20\%) in the $80 \%$ methanol system is important to improve the yield of rutin. Rutin is a glycosylated flavonol, and therefore a small portion of water could enhance its elution compared to the lower performance of $100 \%$ methanol in rutin recovery.
\end{abstract}

Keywords: Rutin; Labisia pumila; solid phase extraction; aqueous methanol; scavenging activity

\section{Introduction}

Rutin (3',4,5,7-tetrahydroxyflavone-3-rutinoside) is one of the attractive plant-based glycosylated flavonoids because of its remarkable pharmacological activities. ${ }^{1}$ This glycoside consists of its aglycone, quercetin and two sugar moieties; glucose and rhamnose. Sometimes, it is called as quercetin-3-O-rutinoside. Quercetin usually coexists with rutin in plants. Quercetin can also be found in intestine after rutin has been hydrolyzed by gastrointestinal microflora. $^{2}$ They are excellent sources of pharmaceutical products for phytotherapy nowadays. ${ }^{3}$ The medical benefits of rutin can be seen from its wide application in more than 130 therapeutic formulations worldwide. ${ }^{4-6}$ Mostly, the formulations are prepared as health supplement and herbal remedy for anti-inflammatory symptoms. Indeed, the demand for natural rutin is on the increase, in line with the increase of scientific evidence on the beneficial effects of rutin.

Numerous studies have been extensively carried out to investigate the extraction methods for high yield of rutin from plant samples. This includes traditional and advanced technological methods as reviewed by Chua. ${ }^{1}$ Recent advancement in extraction technology reveals that ionic liquid and water under subcritical condition could recover polyphenolic compounds from lignocellulosic biomass or plant material. Reflux extraction is a time and cost effective method known for its simple set-up and being easy to operate. It is especially convenient for extraction of phytochemicals from plants because of its temperature and reflux duration control. Sample clean-up process usually follows after extraction for highly complex mixture of samples. Solid phase extraction (SPE) is the commonly employed method for sample clean-up. The principle of SPE strongly depends on the physicochemical properties of its stationary phase, ranging from highly polar to non-polar packing materials. Usually, reversed phase SPE column is used to remove plant impurities such as sugars, proteins and metals prior to analyses, in order to prevent matrix interference and improve data reliability. ${ }^{7-9}$ Previous results indicated that rutin could have the highest adsorption capacity in 
C18 reversed phase. ${ }^{10}$ This long organosilyl ligand phase has higher carbon percentage and lower polarity in chemically bonded packing materials than C8 and C4.

Solvent is the dominant factor not only for extraction, but also for SPE fractionation of plant samples. It acts as a carrier to deliver phytochemicals into medium. The choice of solvent usually follows the principle of "like dissolves like" which explains that solvent with the polarity value near to the polarity of target compound is likely to dissolve the target compound better and vice versa. Since 1924, rutin has been extracted using alcoholic solvents such as ethanol and methanol in many studies. ${ }^{11-13}$ Mostly, $50-60 \%$ of alcoholic solvent could produce the highest yield of rutin from buckwheat. ${ }^{14,15}$ A portion of water would enhance the efficiency of extraction by increasing the diffusion of extractable polyphenols through plant tissues. ${ }^{16}$ Aqueous solvent can increase the polarity of the solvent system for better separation of rutin from complex pharmaceutical and plant samples. ${ }^{17-19}$ Nevertheless, recent advancement of extraction technology revealed that subcritical water or ionic liquid which act as a good hydrogen donor solvent, could effectively recover polyphenolic compounds from lignocellulosic biomass or plant material using hydrothermal treatment. ${ }^{20-22}$

This study was focused on the investigation of rutin recovery from the crude extract of Labisia pumila var. Alata using different percentages of methanol as the eluent in C18 reversed phase SPE. Rutin is one of the key compounds contributing to the previously reported pharmacological activities of this plant. Therefore, plant extract or fraction rich in rutin is believed can enhance the biological effects. The presence of rutin was detected by highly sensitive and reliable analytical technique, namely multiple reaction monitoring. This target analysis was used to monitor the elution of rutin collected from SPE cartridges, even though rutin was present in trace amount. The rutin-rich fraction was then analyzed for its antioxidant capacity against free radicals using colorimetric method. The finding of this study is important for natural rutin recovery from plant-based samples and wastes, particularly on the effect of methanol concentration in SPE.

\section{Materials and Methods}

\section{1. Chemicals and Plant Leaves}

The standard chemical of rutin (97\%) was purchased from Acros Organics (Pittsburgh, USA). HPLC-grade of methanol, n-hexane, ethyl acetate, hydrochloric acid and formic acid were obtained from Merck (Darmstadt, Germany). Sodium carbonate and aluminium chloride were purchased from Fisher Scientific (Pittsburgh, USA). 1-1 diphenyl-2-picrylhydrazyl (DPPH) and L-ascorbic acid were bought from Sigma-Aldrich (St. Louis, MO). Deionised water was generated from Barnstead NANOpure Diamond water purification system (State of Illinois, USA) at
18.2 $\mathrm{M} \Omega-\mathrm{cm}$ resistivity. C18 ec octadecyl-modified silica cartridges (Chromabond, $1000 \mathrm{mg}, 6 \mathrm{~mL}$ ) were bought from Macherey-Nagel (Hoerdt, France). The leaves of $L a$ bisia pumila var. Alata was purchased from Fidea Resources (Selangor, Malaysia). The leaves were rinsed and dried in an oven at $45^{\circ} \mathrm{C}$ for 3 days until constant weight. The dried leaves were ground to approximately $2-5 \mathrm{~mm}$ for further experimental works.

\section{2. Plant Sample Extraction}

The dried and ground leaves $(150 \mathrm{mg})$ of the plant were pre-treated with hexane to remove fatty substances by sonication at $30^{\circ} \mathrm{C}$ for $15 \mathrm{~min}$. The defatted filtrate was then extracted with $100 \mathrm{~mL}$ of $60 \%$ methanol in a reflux system at $75^{\circ} \mathrm{C}$ for an hour. The boiled solvent was evaporated, condensed and returned to the round bottom flask $(500 \mathrm{~mL})$ for rutin extraction. The flask contained plant samples which were immersed by solvent in homogenous condition. This continuous solvent circulation process through vaporization and condensation would enhance the extraction process. The supernatant was collected after extraction and the remaining filtrate was extracted again with new solvent (60\% methanol) under the similar extraction conditions in order to ensure complete extraction of rutin from the plant leaves. The supernatant was combined and dried to a constant weight by a rotary evaporator at $55^{\circ} \mathrm{C}$. The plant crude extract $(27.3 \mathrm{mg})$ was stored at $-20^{\circ} \mathrm{C}$ freezer for the subsequent analysis.

\section{3. Solid Phase Extraction of Rutin}

A reversed phase SPE was carried out to fractionate rutin from the crude extract of the herb using the principle of column chromatography. The C18 ec cartridge with 14\% of carbon content and $45 \mu \mathrm{m}$ of particle size was used for rutin fractionation. The cartridge was preconditioned before use according to the instruction of manufacturer. A 1 $\mathrm{mL}$ crude extract $(60 \mathrm{mg} / \mathrm{mL})$ was prepared and loaded onto the preconditioned cartridge, and eluted with different concentrations of methanol (20-100\%) at a flow rate of 0.25 $\mathrm{mL} / \mathrm{min}$. Each fraction consisted of $1 \mathrm{~mL}$ eluent and screened for rutin detection using an Ultra Performance Liquid Chromatography integrated with tandem Mass Spectrometer (UPLC-MS/MS). The fractions containing rutin would be combined and dried in vacuo for rutin quantitation. The volume of eluent required for rutin fractionation was monitored until completion. The fraction containing rutin was dried and determined for its concentration.

\section{4. UPLC-MS/MS}

The analytical UPLC (Waters Acquity, Milford, MA) system was coupled with a triple quadrupole-linear ion trap tandem mass spectrometer (Applied Biosystems 4000 Q TRAP; Life Technologies Corporation, Carlsbad, CA) 
with an electrospray ionization source. A C18 reserved phase Acquity column $(150 \times 4.6 \mathrm{~mm}, 1.7 \mu \mathrm{m})$ protected by a guard column was used throughout this study. The mobile phase was a binary solvent system consisting of solvent $\mathrm{A}$ (water with $0.1 \%$ formic acid) and solvent $\mathrm{B}$ $\left(\mathrm{CH}_{3} \mathrm{CN}\right)$. The UPLC gradient was: $0-3 \mathrm{~min}, 10 \% \mathrm{~B} ; 3-8$ min, $10-90 \%$ B; 8-12 min, $90 \%$ B; $12-13$ min, $90-10 \%$ B; 13-15 min, $10 \% \mathrm{~B}$ for final washing and equilibration of the column for the next run. The flow rate was $0.25 \mathrm{~mL} /$ min and the injection volume was $5 \mu$ l. All samples were filtered with $0.2 \mu \mathrm{m}$ nylon membrane filter prior to injection. The negative scan mode of multiple reaction monitoring with two transition ions $(\mathrm{m} / \mathrm{z} 609 / 301$ and $\mathrm{m} / \mathrm{z}$ $609 / 151$ ) was used for rutin screening and quantitation. The calibration curve was prepared by using a serial of standard rutin solutions with different concentrations from 0.1 to $1.0 \mathrm{ppm}$. The capillary and voltage of the ion source were maintained at $400{ }^{\circ} \mathrm{C}$ and $-4.5 \mathrm{kV}$, respectively. All other parameters were as follows: nitrogen was used as ion source gas for nebulisation, $40 \mathrm{psi}$; for drying solvent, 40 psi; curtain gas, 10 psi; collision gas, high; declustering potential, $-40 \mathrm{~V}$, and collision exit energy, $-10 \mathrm{~V}$. The scan rate was $1000 \mathrm{amu} / \mathrm{s}$. Data acquisition and data processing were performed using Analyst 1.4.2.

\section{5. Free Radical Scavenging Activity by DPPH Assay}

The scavenging activity of the fractions was compared to crude extract, standard rutin, standard ascorbic acid by using DPPH (1,1-diphenyl-2-picrylhydrazyl) assay. A $5 \mathrm{~mL} \mathrm{DPPH}(0.1 \mathrm{mM})$ in methanol was mixed with $200 \mu \mathrm{L}$ samples with different concentrations. After 30 minutes of incubation in the dark, the absorbance of the solution was measured by using a UV-Vis spectrophotometer (Shimadzu UV-1800, Tokyo, Japan) at $517 \mathrm{~nm}$. The reagent solution without sample was used as blank. The percentage of inhibition was calculated from Equation (1). The inhibitory activity at $50 \%\left(\mathrm{IC}_{50}\right)$ was determined from the curve constructed by Equation (1). The DPPH assay was carried out in triplicate for all samples.

Inhibition $(\%)=[(\mathrm{Ac}-\mathrm{As}) / \mathrm{Ac}] \times 100$

Where: $A c=$ absorbance of blank, As $=$ absorbance of sample or standard

\section{Results and Discussion}

\section{1. Reflux Extraction for Plant Crude Extract}

A reflux system was set up to extract phytochemicals from the leaves of L. pumila in $60 \%$ methanol. This continuous solvent evaporation and condensation process of solid-liquid extraction technique is an effective method for phytochemical extraction because of the ease of operation at reasonable cost. The solvent system $(60 \%$ methanol) was chosen based on the finding of previous study conducted by the same group of researchers who did the extraction for L. pumila. ${ }^{23}$ Alcoholic solvent is well known as the solvent of choice for phytochemical extraction, especially for polyphenols and terpenoids. ${ }^{24}$ Since methanol is more polar than ethanol, methanol is likely to be better in penetrating plant cellular membranes than ethanol for phytochemical extraction. ${ }^{25}$ However, methanol might not be the solvent of choice for those researchers who would like to perform cell-based assays because of high cytotoxicity of methanol. ${ }^{26}$ Pure methanol was also found to be less effective than aqueous methanol. ${ }^{27}$ In particular, rutin is a glycosylated quercetin with two sugar moieties. Therefore, a portion of water was necessary to further increase the solvent polarity for the enhancement of extraction efficiency. ${ }^{28}$ According to Ammar et al., ${ }^{29}$ the type of solvent and the method of extraction are the most important factors for the extraction of bioactive compounds from plant samples. Approximately, $18.2 \%$ of crude extract was obtained in the present study. The result was found to be higher than the extraction yield of the similar herbal plant in $100 \%$ ethanol $(6.0 \%)$ and $100 \%$ water $(13.4 \%)$ reported by Azrie et al.. ${ }^{30}$

In comparison with rutin content in the crude extract, the present study produced the extract with rutin concentration of $1.41 \mathrm{mg} / \mathrm{g}$ extract which was comparable to the previous results which ranged from $0.46-2.12 \mathrm{mg} / \mathrm{g}$ extract $^{31}$ and $0.73-2.79 \mathrm{mg} / \mathrm{g}$ extract. ${ }^{32}$ The result of this study was found to be higher than the findings of Karimi et al.. ${ }^{33-35}$ Although they are from a similar research group, a broad range of rutin content $(4.60-116.85 \mu \mathrm{g} / \mathrm{g}$ extract) was observed. Hence, the variance in rutin content is not only attributed to the solvent system, but also the extraction conditions such as temperature, time and extraction method, as well as the variety and maturity stage of the herb.

\section{2. Reversed Phase Column Fractionation for Rutin}

A C18 reversed phase column was used for rutin fractionation from the plant crude extract using the eluent system of methanol at different concentrations (20-100\% methanol). It was found that the total volume of eluent (line bar) and the volume required (dot bar) for rutin elution were varied from $20-100 \%$ of methanol as presented in the primary axis of Figure 1. Similarly, the concentration of rutin eluted from the column also varied at different solvent systems as presented in the secondary axis of Figure 1 . The eluent system of $20 \%$ methanol required the largest volume of solvent to be discarded before rutin elution, as well as the largest volume of solvent required for rutin elution from the SPE column, but the lowest recovery of rutin $(\sim 18 \%)$ in the fractionation. As the concentration of methanol was increased, the capacity ratio $\left(\mathrm{k}^{\prime}\right)$ decreased which resulted in a faster elution on account of a shorter retention time of eluent in the stationary phase. 


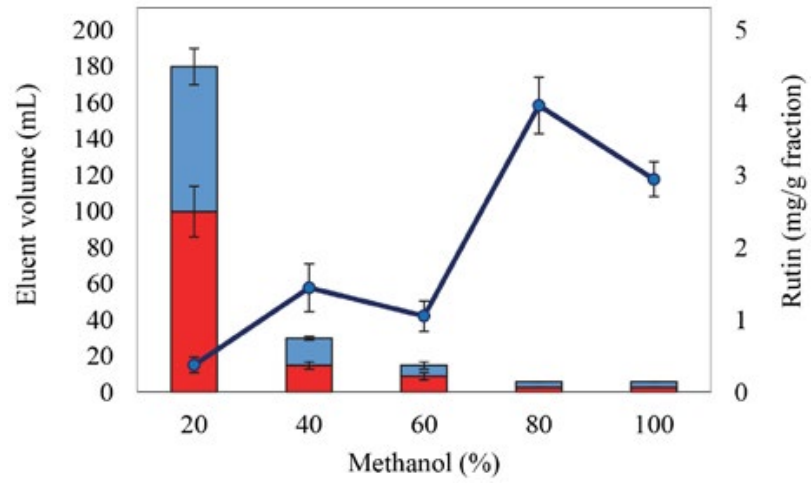

Figure 1. Total volume of eluent (line bar) and volume of eluent containing rutin (dot bar) at the primary axis, and rutin fractionated (line graph) from the methanolic system of solid phase extraction at the secondary axis

Therefore, rutin must be highly soluble in that particular eluent system, so that it can follow the eluent flowing out from the packed column quickly.

As the concentration of methanol was increased, the volume of eluent required for rutin elution was reduced significantly. Rutin was detected at the first 1-mL of elution for the solvent systems of 80 and $100 \%$ methanol. Both solvent systems required small volume $(3 \mathrm{~mL})$ for complete rutin elution, and $80 \%$ methanol produced the highest recovery $69.5 \%$ among the solvent systems. This percentage was comparable to the recovery of rutin in the solvent system of $60 \%$ methanol. However, $60 \%$ methanol was not effective enough because higher volume of eluent was required for rutin elution. Therefore, the affinity of rutin in the $80 \%$ methanol system appeared to be the highest among the methanolic systems. This is because rutin could be eluted from the column at the smallest volume of solvent and the highest recovery. A small portion of water $(20 \%)$ was required for the optimum level of rutin elution. Thus, the $100 \%$ methanol system does not seem to be the most effective solvent system for rutin elution. The observation was not in good agreement with the findings of Bulgarian researchers who reported $100 \%$ methanol could recover the highest content of rutin, isoquercitrin, narcissin and astragalin using C18 SPE column for the Euro- pean Bupleurum species, namely B. baldense Turra and $B$. affine Sadler. ${ }^{36}$ Nevertheless, the recovery of the flavonoids including rutin using $75 \%$ methanolic eluent still exhibited the second highest results which were very close to the data attained by elution with $100 \%$ methanol.

Based on the Hansen solubility parameters, rutin appears to be well dissolved in the eluent system of $80 \%$ methanol. This is because rutin displays the lowest distance $\left(9.44 \mathrm{MPa}^{1 / 2}\right.$ ) from the mass center of Hansen sphere in this solvent system (Table 1). The lower distance can provide better miscibility of rutin in the solvent system. The distance is calculated by the solvent blend formulation which is based on the square root of the sum of the difference between partial cohesive energy of solvent and rutin. ${ }^{37}$ The energy consists of dispersion, hydrogen bonding and polar bonding which can be estimated from the group contribution method. ${ }^{38}$ The Hansen solubility parameters can describe the solubility of solute in solvent better than Hildebrand solubility and $\log \mathrm{P}$ value. ${ }^{39}$ Hildebrand parameter could only describe the solubility of solute in non-polar and non-hydrogen bonding solvent, whereas the one dimensional partition coefficient which is expressed as $\log \mathrm{P}$ is very limited for ionizable compound like rutin. ${ }^{38}$ Rutin has many hydroxyl groups in which their protons are easily released in aqueous based solvents (alcohol and water). In the present study, only half of the rutin content was recovered under the water free eluent. The crucial requirement for a small portion of water has also been highlighted in polyphenol extraction ${ }^{16}$ and SPE fractionation in many studies. ${ }^{17-19}$ Most probably, the preference of sugar moieties in the molecular structure of rutin is in the aqueous medium, even though its aglycone, quercetin is highly soluble in methanol.

By considering the effectiveness of fractionation, $80 \%$ methanol could produce about $60.66 \mu \mathrm{g}$ rutin in a gram of fraction in a milliliter of eluent which was the highest performance among the other solvent systems (13.84-60.66 $\mu \mathrm{g}$ rutin/g fraction/mL eluent). This information is very important, especially for those researchers who would like to recover rutin by using the minimum level of solvent consumption. The performance of $100 \%$ methanol was found

Table 1. Rutin solubility in different solvent systems based on Hansen solubility parameters

\begin{tabular}{ccccc}
\hline Methanol (\%) & Dispersion $(\boldsymbol{\delta} \mathbf{D})$ & $\begin{array}{c}\text { Hansen solubility parameters }\left(\mathbf{M P a}^{\mathbf{1} 2}\right) \\
\text { Polar bonding }(\mathbf{d P})\end{array}$ & Hydrogen bonding $(\boldsymbol{\delta} \mathbf{H})^{\text {Distance }^{*}}$ \\
\hline Rutin & 19.30 & 16.10 & 25.40 & - \\
Water & 15.50 & 16.00 & 42.30 & 18.53 \\
20 & 15.34 & 15.26 & 38.30 & 15.16 \\
40 & 15.18 & 14.52 & 34.30 & 12.23 \\
60 & 15.02 & 13.78 & 30.30 & 9.13 \\
80 & 14.86 & 13.04 & 26.30 & 10.43 \\
100 & 14.70 & 12.30 & 22.30 & \\
\hline
\end{tabular}

* Distance $=\sqrt{4\left(\delta D_{s}-\delta D_{r}\right)^{2}+\left(\delta P_{s}-\delta P_{r}\right)^{2}+\left(\delta H_{s}-\delta H_{r}\right)^{2}}$

Where s denotes for solvent and $\mathrm{r}$ denotes for rutin 

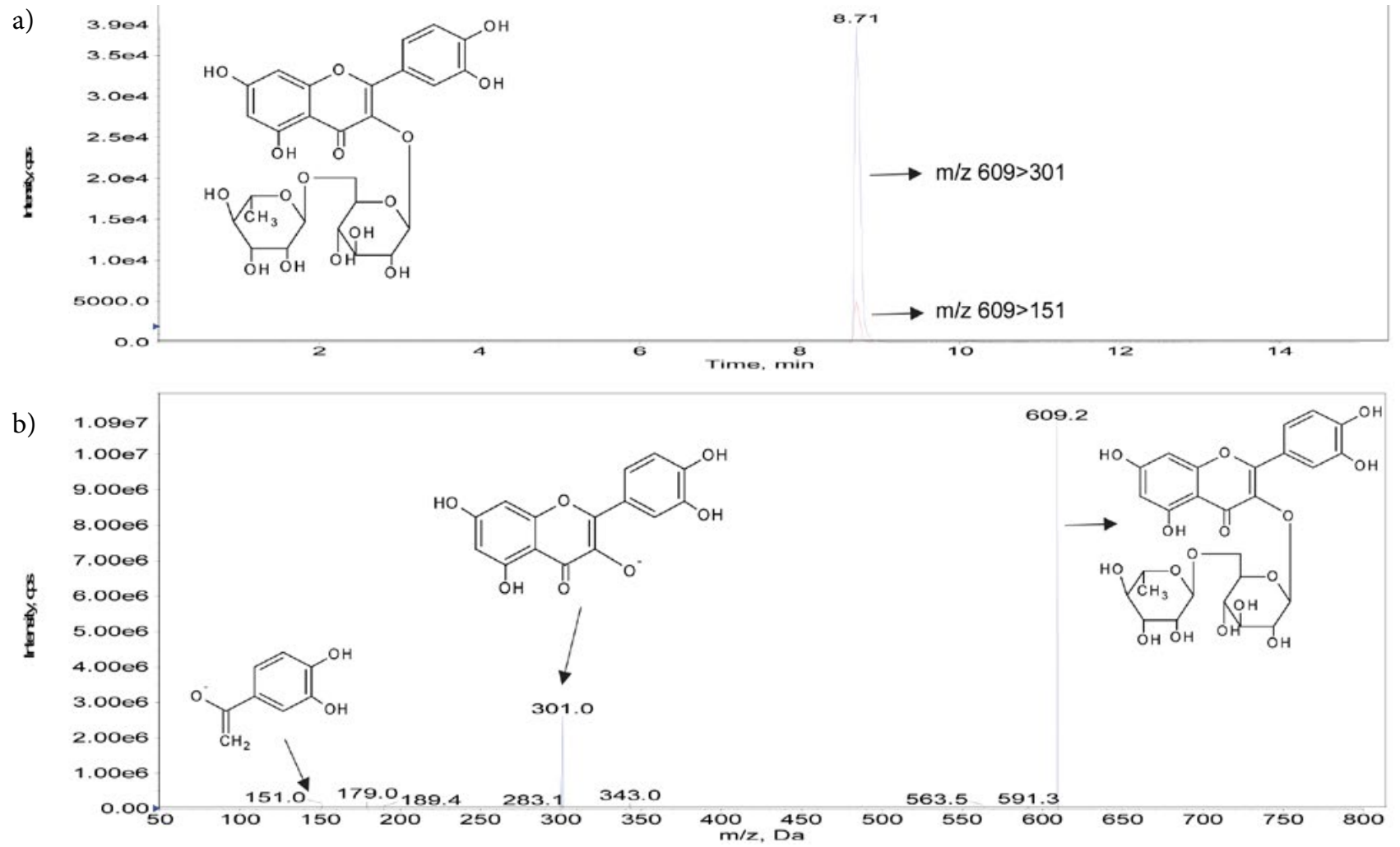

Figure 2. (a) Two transition ions of rutin peaks in multiple reaction monitoring and (b) mass fragmentation of rutin at the negative ion mode

to be the second highest, which was about $52.27 \mu \mathrm{g}$ rutin in a gram of fraction in a milliliter of eluent. The content of rutin was increased from $0.85 \pm 0.16 \mathrm{mg} / \mathrm{g}$ plant leaves $(0.08 \% \mathrm{w} / \mathrm{w})$ or $1.41 \pm 0.54 \mathrm{mg} / \mathrm{g}$ crude extract $(0.14 \% \mathrm{w} / \mathrm{w})$ after reflux extraction, to $3.96 \pm 0.39 \mathrm{mg} / \mathrm{g}$ fraction $(0.40 \% \mathrm{w} / \mathrm{w})$ after fractionation using $80 \%$ methanol as the eluent. The increment was about 2 -fold after extraction and 4 -fold after fractionation. The quantitation of rutin was measured by UPLC-MS/MS using the multiple reaction monitoring of two transition ions such as $\mathrm{m} / \mathrm{z} 609>301$ and $\mathrm{m} / \mathrm{z} 609>151$ at negative ion mode as shown in Figure 2.

\section{3. Scavenging Activity of Rutin Fraction}

The quality of rutin fraction was evaluated based on its scavenging activity using DPPH assay compared to standard chemicals such as rutin and ascorbic acid. The free radicals generated from $\mathrm{DPPH}$ were scavenged by antioxidants in a concentration dependent manner. This method measured the colour change based on the reduction of purple-coloured free radical $\mathrm{DPPH}^{*}$ to yellow-coloured 2,2-diphenyl-1-picrylhydrazine (DPPH-H). The colour density was recorded by a UV-Vis spectrophotometer at $517 \mathrm{~nm}$. The results showed that $\mathrm{IC}_{50}$ for standard rutin and ascorbic acid was 122 and $84 \mathrm{ppm}$, respectively. The lower $\mathrm{IC}_{50}$ value indicates the lower amount of sample required to inhibit $50 \%$ of free radicals which means the sample has higher scavenging activity. The antioxidant capacity of standard rutin is comparable to ascorbic acid which is a well-known antioxidant compound. The $\mathrm{IC}_{50}$ of rutin fraction from the $80 \%$ methanol eluent system was 800 ppm which was 6 times lower scavenging activity than standard rutin, but almost 2 times higher scavenging activity than its crude extract (Table 2). Therefore, reversed phase fractionation increased the content of rutin in the plant sample, as well as improved its antioxidant capacity. The observation also explains that rutin could be the major radical scavenger. The increase of rutin content in the fractionated sample was found to increase its scavenging activity significantly.

Table 2. Scavenging activity of standard chemicals and plant samples at 50\% inhibition

\begin{tabular}{lc}
\hline Sample & IC $_{\mathbf{5 0}}$ ( $\left.\mathbf{p p m}\right)$ \\
\hline Standard ascorbic acid & 84 \\
Standard rutin & 122 \\
Crude extract & 1500 \\
$80 \%$ methanol rutin fraction & 800 \\
\hline
\end{tabular}

\section{Conclusion}

The detection of rutin has been reported by many investigators in L. pumila recently. It could be the prominent flavonol glycoside in the herbal plant which contributes to the significant pharmacological activities. Therefore, this study investigated the effects of methanol con- 
centration for rutin recovery in SPE. A reserved phase SPE system could recover about $70 \%$ of rutin from the crude extract of $L$. pumila var. Alata using $80 \%$ methanol as the eluent. The rutin rich fraction was found to exhibit higher scavenging activity than crude extract, but the value was still lower than standard rutin.

\section{Acknowledgement}

The authors would like to thank Universiti Teknologi Malaysia for internal grant (GUP 05J84), and Ministry of Higher Education Malaysia for HiCoE grant (4J263) to carry out the research activities. We also highly appreciate our internship student, Ms. Lee Si Ning to replicate some experimental works.

\section{References}

1. L. S. Chua, J. Ethnopharmacol. 2013, 150, 805-817. DOI:10.1016/j.jep.2013.10.036

2. G. Chen, H. Zhang, J. Ye, Anal. Chim. Acta 2000, 423, 69-76. DOI:10.1016/S0003-2670(00)01099-0

3. Y. Yang, F. Zhang, Ultrason. Sonochem. 2008, 15, 308-313. DOI:10.1016/j.ultsonch.2007.05.001

4. J. E. F. Reynolds, Martindale-The Extra Pharmacopoeia, $31^{\text {st }}$ ed., The Royal Pharmaceutical Society, Council of the Royal Pharmaceutical Society of Great Britain, London, 1996, pp. 1679-1680.

5. W. Q. Sun, J. F. Sheng, Handbook of Natural Active Constituents, Chinese Medicinal Science and Technology Press, Beijing, 1998, pp. 2240-2316.

6. I. Erlund, T. Kosonen, G. Alfthan, J. Maenpaa, K. Perttunen, J. Kenraali, J. Parantainen, A. Aro, Eur. J. Clin. Pharmacol. 2000, 56, 545-553. DOI:10.1007/s002280000197

7. S. Y. Yoon, W. J. Choi, J. M. Park, J. W. Yang, Biotechnol. Tech. 1997, 11, 553-556. DOI:10.1023/A:1018434704902

8. E. Aehle, S. R. L. Grandic, R. Ralainirina, S. Baltora-Rosset, F. Mesnard, C. Prouillet, J. C. Maziere, M. A. Fliniaux, Food Chem. 2004, 86, 579-585.

DOI:10.1016/j.foodchem.2003.10.006

9. J. Wang, F. A. Wu, H. Zhao, L. Liu, Q. S. Wu, Afr. J. Biotechnol. 2008, 7, 2147-2155.

10. B. Buszewski, S. Kawka, Z. Suprynowicz, T. Wolski, J. Pharm. Biomed. Anal. 1993, 11, 211-215.

DOI:10.1016/0731-7085(93)80199-B

11. C. E. Sando, J. U. Lloyd, J. Biol. Chem. 1924, 737-745.

12. H. F. Koones, N. J. Clifton, Extraction of rutin, United States Patent Office: 2,450,555, 5 Oct 1948.

13. F. Fathiazad, A. Delazar, R. Amiri, S. D. Sarker, Iranian J. Pharm. Res. 2006, 5, 222-227.

14. S. Kreft, M. Knapp, I. Kreft, J. Agr. Food Chem. 1999, 47, 4649-4652. DOI:10.1021/jf990186p

15. K. H. Kim, K. W. Lee, D. Y. Kim, H. H. Park, I. B. Kwon, H. J. Lee, Bioresour. Technol. 2005, 96, 1709-1712.

DOI:10.1016/j.biortech.2004.12.025
16. E. Altiok, D. Baycin, O. Bayraktar, S. Ulku, Sep. Purif. Technol. 2008, 62, 342-348. DOI:10.1016/j.seppur.2008.01.022

17. J. Dai, R. J. Mumper, Molecules, 2010, 15, 7313-7352. DOI:10.3390/molecules15107313

18. Z. Legnerova, D. Satınsky, P. Solich, Anal. Chim. Acta 2003, 497, 165-174. DOI:10.1016/j.aca.2003.07.007

19. B. Buszewski, S. Kawka, T. Wolski, Chromatographia 1993, 35, 311-316. DOI:10.1007/BF02277516

20. H. Zeng, Y. Wang, J. Kong, C. Nie, Y. Yuan, Talanta 2010, 83, 582-590. DOI:10.1016/j.talanta.2010.10.006

21. M. Grilc, B. Likozar, J. Levec, Chem CatChem. 2016, 8, 180191. DOI:10.1002/cctc. 201500840

22. S. Machmudah, Wahyudiono, H. Kanda, M. Goto, ARPN J. Eng. App. Sci. 2016, 11, 9509-9518.

23. L. S. Chua, N. A. Latiff, S. Y. Lee, C. T. Lee, M. R. Sarmidi, R. A. Aziz, Food Chem. 2011, 127, 1186-1192.

DOI:10.1016/j.foodchem.2011.01.122

24. A. Pandey, S. Tripathi, J. Pharmacog. Phytochem. 2014, 2, $115-119$.

25. G. X. Wang, Vet. Parasitol. 2010, 171, 305-313.

DOI:10.1016/j.vetpar.2010.03.032

26. P. Tiwari, B. Kumar, M. Kaur, G. Kaur, H. Kaur, Int. Pharm. Sci. 2011, 1, 98-106.

27. D. Xiao, P. M. Davidson, D. H. D’Souza, J. Lin, Q. Zhong, J. Food Eng. 2010, 100, 194-200.

DOI:10.1016/j.jfoodeng.2010.03.044

28. M. Bimakr, R. A. Rahman, F. S. Taip, A. Ganjloo, L. M. Salleh, J. Selamat, A. Hamid, I. S. M. Zaidul, Food Bioprod. Process. 2011, 89, 67-72. DOI:10.1016/j.fbp.2010.03.002

29. I. Ammar, M. Ennouri, H. Attia, Ind. Crop. Prod. 2015, 64, 97-104. DOI:10.1016/j.indcrop.2014.11.030

30. A. M. Azrie, A. Luqman Chuah, K. Y. Pin, J. Chem. Pharm. Res. 2014, 6, 172-176.

31. M. H. Ibrahim, H. Z. E. Jaafar, E. Karimi, A. Ghasemzadeh, Sci. World J. 2014, 2014, 360290.

32. Z. Ismail, H. K. Beh, M. S. R. Hamil, G. Ghafar, M. A. A. Saeed, A. H. Memon, S. Hashim, Publication number: WO2016093692 A1. 16 June 2016.

33. E. Karimi, H. Z. E. Jaafar, S. Ahmad, 2011 Molecules 2011, 16, 4438-4450.

34. E. Karimi, H. Z. E. Jaafar, A. Ghasemzadeh, M. H. Ibrahim, Aus. J. Crop Sci. 2013, 7, 1016-1023.

35. E. Karimi, H. Z. E. Jaafar, Molecules 2011, 16, 6791-6805. DOI:10.3390/molecules16086791

36. R. Gevrenova, N. Denkov, D. Zheleva-Dimitrova, Pharmacia 2014, 61, 17-23.

37. The Official Hansen Solubility Parameter Site, Http://www. Hansen-Solubility.com (Accessed: 20 September 2015).

38. C. M. Hansen, Hansen Solubility Parameters, in A User's Handbook, $2^{\text {nd }}$ ed. CRC Press, Boca Raton, 2007.

DOI:10.1201/9781420006834

39. J. Gao, Using Hansen solubility parameters (HSPs) to develop antioxidant-packing film to achieve controlled release. Michigan State University, Thesis for Master of Science, 2014. 


\section{Povzetek}

Ekstrakcija z refluksom je bila uporabljena za pripravo osnovnega ekstrakta iz listov Labisia pumila var. Alata. Za izolacijo rutina $\mathrm{z}$ visokim izkoristkom je bil ta v nadaljevanju obdelan s C18 ekstrakcijo v trdni fazi z 20-80 \% metanolom. Pri tem je bil z naraščajočo vsebnostjo metanola potreben manjši volumen eluenta, prav tako je naraščal tudi izkoristek, vendar je ta v čistem metanolu rahlo padel. Z $80 \%$ metanolom je bilo izoliranega približno $70 \%$ rutina. Bogata frakcija izolata $\mathrm{z}$ rutinom je dosegla $3.96 \mathrm{mg}$ rutina /g frakcije, kar je 4-krat več kot v osnovnem ekstraktu. Tudi antioksidacijska aktivnost se je 2-krat povečala v primerjavi z osnovnim ekstraktom. Na boljši izkoristek rutina lahko vpliva voda (20 \%) v $80 \%$ sistemu z metanolom. Rutin je namreč glikoziliran flavonol in majhen delež vode lahko pospeši elucijo v primerjavi s $100 \%$ metanolom. 